\title{
Development agents and their role in cushioning the pastoralists of Isiolo Central Sub-County, Kenya, against negative effects of climate variability
}

\author{
Anastasia Wanjiku Kagunyu ${ }^{1 *}$, Elias Gitonga Thuranira ${ }^{2}$ and Joseph Gatura Wanjohi ${ }^{3}$
}

\begin{abstract}
Climate variability is a natural phenomenon, and of late, it is becoming more frequent and more intensive especially in the arid and semi-arid lands (ASALs). This has affected the livelihoods and the coping strategies of the pastoral communities of the ASALs of Kenya. As a result, there was need to conduct a study and assess the type of development agents existing in the region and the type of assistance they provided. This study applied household interviews, focus group discussions and key informant interviews to collect data. Quantitative data was analysed using SPSS software and descriptive statistics were run. The study revealed that there are various development agents who assist the pastoralists of Isiolo, namely government departments, NGOs and faith-based organizations. The type of assistance given included resettlements, human and livestock medicine, restocking, destocking, subsistence funds for the old people, relief foods and livestock feeds. The study findings also indicate that the assistance given was inadequate and this was attributed to poor leadership, selfishness and marginalization. In most cases inappropriate interventions were put in place such as providing maize to the community when what they really needed was livestock for restocking. For the pastoralists of Isiolo County to benefit from development agents there is need for proper coordination of development agents assisting livestock communities in Isiolo County. There is also need for government departments, NGOs and faith-based organizations to ensure full engagement and effective participation of the local communities in the conception, design and implementation of sustainable solutions to reverse the effects of climate variability.
\end{abstract}

Keywords: Climate, Variability, Development agents, Pastoralists, Assistance

\section{Introduction}

Climate variability refers to variations in the mean state and other statistics (such as standard deviations and the occurrence of extremes) of the climate on all temporal and spatial scales beyond that of individual weather events. IPCC (2014) gives indicators of climate variability as extended droughts, floods and conditions that result from periodic El Niño and La Niña events. Huho (2016) indicates that Africa, and in particular the Greater Horn of Africa (GHA), is one of the areas in the world that experience the severest impacts of climate

\footnotetext{
* Correspondence: festcy2011@gmail.com

${ }^{1}$ Kenya Agricultural and Livestock Research Organisation-Sericulture, P.O. Box

7116-01000, Thika, Kenya

Full list of author information is available at the end of the article
}

change. According to Connolly-Boutin and Smit (2016) on sub-Saharan Africa, climate change has caused increased droughts and floods which impede people's ability to grow food and rear livestock.

In Kenya there are various indicators of climate variability which include erratic rainfall patterns, persistent droughts and vanishing glaciers on Mt. Kenya (Kanywithia 2010). In the ASALs, for instance, frequent droughts and floods have led to not only chronic famines and hunger but also dwindling of the pastoral economy, posing the greatest threat to rural livelihoods (Huho 2016). Studies show that drought poses serious challenges for populations whose livelihoods depend principally on natural resources (Below et al. 2010; Nicholson 2014). Kenya's arid and semi-arid lands (ASALs), which have faced increasing 
drought frequency and intensity since the 1960s, are one of the most vulnerable and drought-prone regions in the country (Nkedianye et al. 2011). Despite this exposure and sensitivity to frequent droughts, the pastoral economy in the ASALs of Kenya accounts for $90 \%$ of all employment opportunities and 95\% of family income and livelihood security (Republic of Kenya 2012). Given the changing global climate, coupled with expected increase in evapotranspiration due to increased temperatures, the ASALs are expected to experience frequent climatic extremes, increased aridity, increased water stress, diminished yields from rain-fed agriculture and increased food insecurity and malnutrition (Thornton and Lipper 2014).

Natural disasters such as drought, floods, earthquakes and storms are not new to the arid and semi-arid areas. Traditionally, pastoralists have used indigenous coping strategies to address these disasters (Kimani et al. 2015). Their coping mechanisms appear to have worked well since time immemorial but recent studies by Yazan et al. (2012) and Kimani et al. (2015) have shown that climate variability has weakened their coping strategies. This led to the emergence of this study which aimed at assessing whether livestock communities in one of the ASAL areas of Kenya are accessing external assistance and the type of assistance offered.

The study sought to answer the following questions: are there development organizations involved in assisting the pastoralist community in the study site whenever there are climate related disasters? What type of assistance is provided by the development agents? What is the attitude of livestock keepers towards the assistance given?

\section{Study site}

This study took place in Isiolo Central, a sub-county of Isiolo County situated in northern Kenya. The site was selected by the researcher due to inadequate resources and transport means which would not have been enough to enable the researcher to work in other parts of Isiolo. Isiolo Sub-County is one of the six administrative divisions of Isiolo County and has a population of 70,357 according to the Kenya National Bureau of Statistics report of 2009. This region is inhabited by pastoralists and agro-pastoralists such as the Turkana, Borana, Rendille, Somali and Ameru communities, with the Boranas forming the largest portion of the population (G.O.K 2013).

The sub-county is semi-arid since it is hot and dry most of the year. It has two rainfall seasons, the long and short rains, with the long rains coming mainly in March and May while the short rains come between October and November (G.O.K 2012). Rainfall is scarce and unreliable, which means it cannot support perennial agricultural crops (G.O.K 2013). The county is covered by vast areas of shrubs and grasslands suitable for ranching.

\section{Administrative and political units of Isiolo Sub-County} Isiolo Sub-County has the highest number of wards (five) they include Wabera, Bulla Pesa, Burat, Ngaremara and Oldonyiro (G.O.K 2013). The sub-county has an area of $3269 \mathrm{~km}^{2}$ (GOK 2013). The headquarters of Isiolo County is based in Isiolo Central Sub-County. The map of Isiolo shows the location of Isiolo Central SubCounty Figure 1.

\section{Major economic activity of Isiolo Sub-County Livestock production}

The major economic activity of the inhabitants of Isiolo Sub-County is livestock production (G.O.K 2005, 2013). The livestock reared include cattle (Borana breed), camels, sheep, goats, donkeys and poultry (G.O.K 2012). The main mode of livestock production is free range whereby livestock graze and browse freely in the extensive rangeland. Dairy farming is also practised on a small scale along river Isiolo. The dairy cattle comprise crosses of local breeds (Zebu or Borana), with Fresian, Guernsey, Jersey and Sahiwals. The amount of milk produced in the County is not sufficient for the inhabitants and much of the milk consumed in Isiolo town comes from Meru County (G.O.K 2013).

\section{Methods}

This study was cross-sectional in nature, and both qualitative and quantitative methods of data collection were employed. Data were collected using household interviews, direct observation, focus group discussions and key informant interviews. Qualitative data were analysed according to the themes in the research objectives. Quantitative data were analysed using SPSS software.

\section{Sample size and sampling procedure}

A total of 400 respondents were interviewed. These consisted of 206 men and 194 women. Men are the household heads and women were interviewed in cases where men were not found in the homesteads. To get the respondents, the researcher visited the senior chief of the area who assisted her to identify three villages based on the following reasons: majority of the population being pastoralists, accessibility of the villages and security of the study sites. The villages identified were Kambi Odha, Kambi Mbulle and Kambi Garba. The researcher had initially anticipated using a ready-made household sampling frame from the chief's office to select the respondents, but the area chiefs were reluctant to give named lists of their villages' inhabitants, probably 


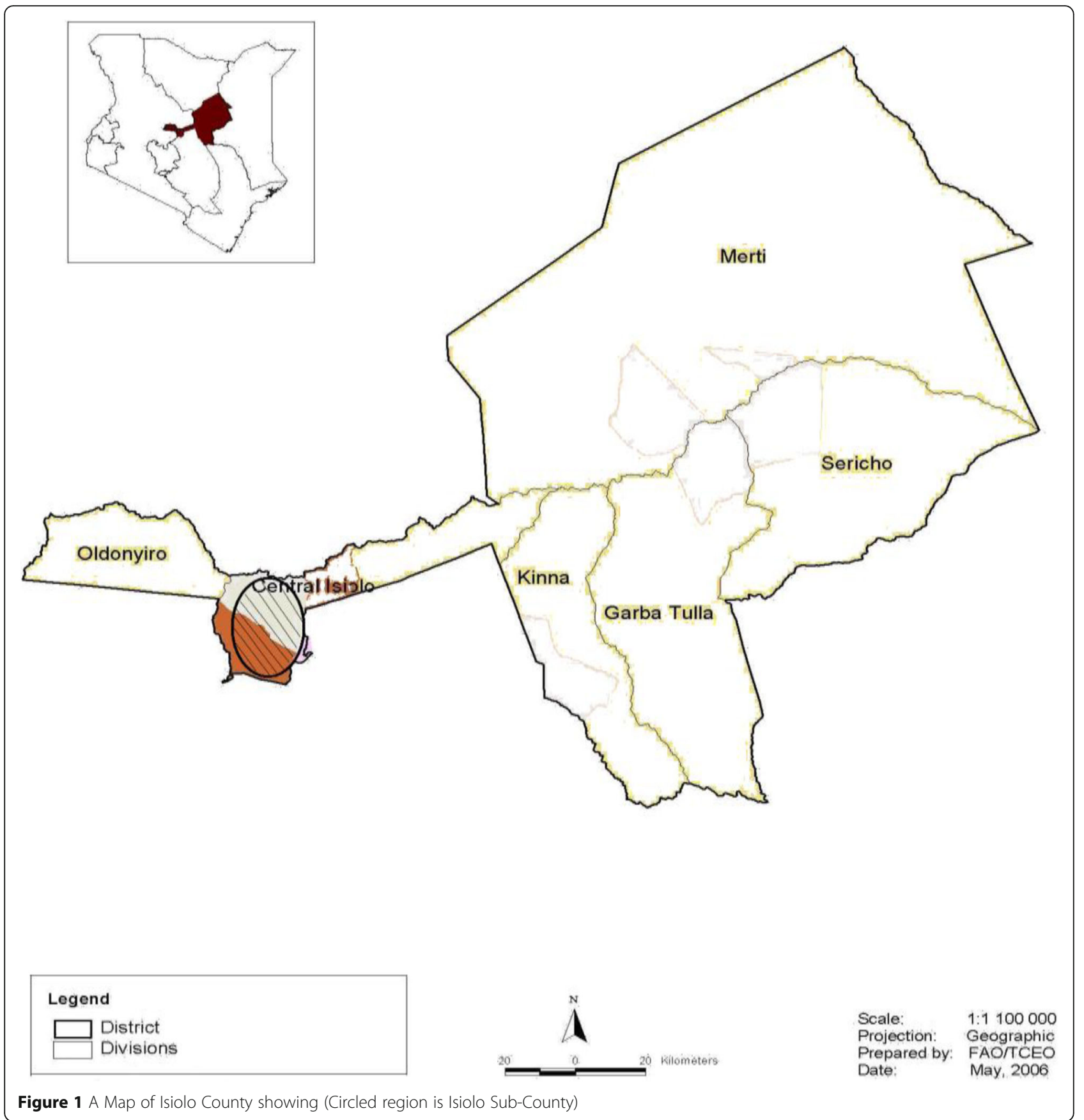

because of the prevailing insecurity situation at the time of the study.

To arrive at the designated sample size, systematic random sampling was used. Sketch maps of the three villages were drawn, and landmarks in the selected settlements. These included chiefs' camps, shopping centres, schools, churches, mosques and roads. Straight lines were drawn connecting two landmarks, for instance, a land-mark in the north was joined to a land-mark in the south and land-marks in the west were joined to those in the east. Respondents were interviewed along those lines, starting from the first landmark four households were skipped and the fifth household was considered for the interview and this exercise continued until the designated sample size was achieved.

\section{Household interviews}

Household interviews were conducted with household heads, male or female, through the administration of a questionnaire to the respondents. The enumerators were recruited and trained before data collection. Where a household was identified for the interview and the head 
was not present at the time of the visit, effort was made to revisit the household until one of them was found and interviewed. The questions answered by household heads were on the external agencies assisting the pastoralists to cope with various disasters, the type of assistance given and whether the assistance given was satisfactory or not.

\section{Focus group discussions}

The researcher had initially anticipated conducting three focus group discussions, but it was not possible due to insecurity. Therefore, only two focus group discussions were conducted, and each group had 10 participants who were selected purposively. Each group had men and women who were above 45 years of age. The issues discussed included development agents existing in the region, type of assistance given and pastoralists' attitude towards the assistance offered.

\section{Key informant interviews}

Key informants were selected purposively, focusing on those informants with rich information on the topic and who were willing to share the information in order to increase the scope or range of our data. A total of 12 key informants were interviewed, which included the chief's representative of various villages, the Senior chief for Isiolo Central, a biometrician with Ewaso Nyiro Development Authority, project coordinator from Food for the Hungry International, Livestock officer, Agricultural officer, project coordinator Aridlands, Kenya Forest Service officer, water and irrigation officer and an officer from National Agricultural and Livestock Extension Programme.

\section{Data processing and analysis}

Data obtained from focus group discussions and key informants were sorted out and interpreted in relation to the research general objective. On the other hand, quantitative data derived from the household interviews were edited, coded and analysed using Statistical Package for Social Sciences (SPSS) software version 20 spreadsheets. Descriptive statistics were run to give frequencies and percentages.

\section{Results}

\section{Organizations that give assistance to the pastoralists}

The findings study indicated that there are organizations that assisted the community during times of calamities. They include government departments, NGOs and faithbased organizations. The organizations were ranked according to their level of involvement and contributions. A majority $(70 \%)$ of the respondents said that government departments were highly involved in offering assistance to the respondents whenever they were faced with the negative effects of climate variability. They were followed by 25.7\% who ranked NGOs as the second. Faith-based organizations had $3.2 \%$, while $1 \%$ of the respondents said that there were no agents which assisted them. Figure 2 gives the external agents which assist the respondents when faced with natural calamities.

\section{The type of assistance given by government institutions and other organizations}

Figure 3 shows the type of assistance that respondents got from the external agents. Half (50\%) of the respondents responded that they were given relief food and feeds for livestock. This was mainly done by the government whenever there were droughts and floods. On the other hand, $22 \%$ indicated that they were given medicine, while $17 \%$ respondents stated that they were relocated whenever there were floods and ethnic conflicts. Other (7.5\%) respondents said that destocking and restocking were another form of assistance given. Destocking programmes were initiated by the government during the time of droughts to avoid massive losses of livestock. Key informants reported that after severe droughts, pastoralists were given a few livestock to build a herd. Government departments, including Aridlands and Ewaso Nyiro Development Authority (EDA), and NGOs were reported as being involved in restocking initiatives. Another $2.5 \%$ of respondents stated that subsistence funds are given to the elderly, while $1 \%$ indicated that no assistance was given.

\section{Respondents' attitudes towards assistance given}

The study findings suggest that the government, NGOs and faith-based organizations had made efforts to assist pastoralists whenever they were faced with the negative effects of climate variability. Majority (69\%) of the respondents stated that the type of assistance they got was not enough. According to the respondents, the food given was very little, it was never available on time and sometimes it was given after three months. The other problem was that the assistance given sometimes never



Figure $\mathbf{2}$ Institutions and organizations and assistance offered during calamities 


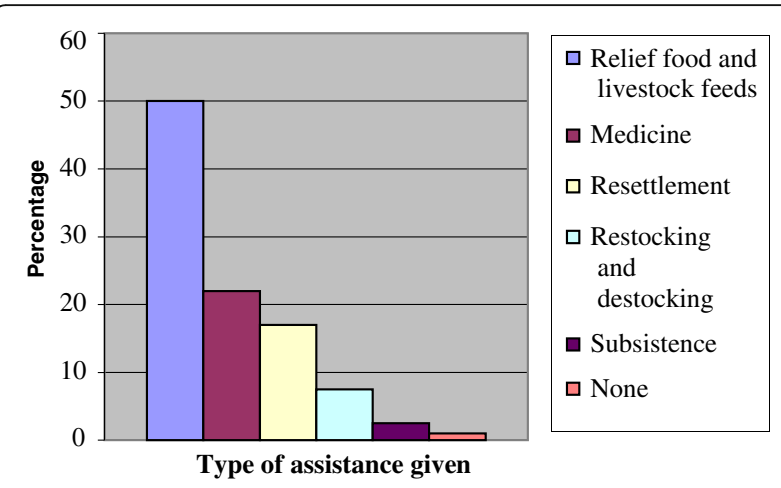

Figure 3 Type of assistance given by the Government and other organizations

reached the intended beneficiaries. Relief food was usually intended for the very poor, but in many cases, the largest share ended up in the hands of the rich. Thirty per cent of the respondents said that the type of assistance given was good, while $1 \%$ said that no assistance was ever given.

\section{Adaptive strategies not implemented on a large scale}

Study findings indicate that there were some important adaptive strategies which were not implemented on a large scale. Figure 4 shows that $38.5 \%$ of the respondents mentioned water harvesting technologies, $35.5 \%$ talked of restocking programmes and $17.8 \%$ listed irrigation and agricultural inputs as potentially adaptive strategies. On the other hand, $2.5 \%$ of respondents said security is not given the attention it deserves and $2.3 \%$ said planting of trees was needed. Lastly, $1.8 \%$ of the respondents talked of unemployment. One of the key informants suggested that if a slaughter house was constructed in Isiolo County, it would save livestock losses being encountered by pastoral communities while waiting for the Kenya Meat Commission (KMC) to buy their livestock when they are on the verge of death.

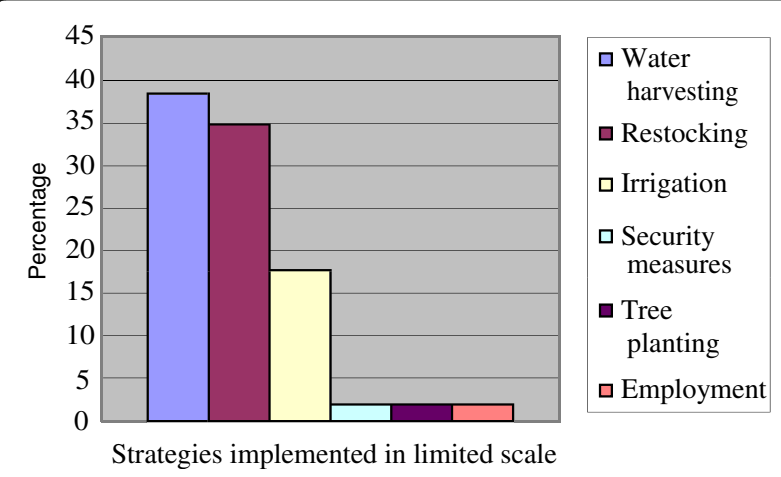

Figure 4 Adaptive strategies not implemented on a large scale
Respondents' perceptions of why some adaptive strategies were implemented on a limited scale

Various reasons were given by respondents regarding why some suitable adaptive strategies were not implemented on a large scale - these reasons included lack of pastoralist representatives when important decisions were being made-this was stated by $40 \%$ of the respondents. On the other hand, $22.3 \%$ of the respondents said that this was due to poor leadership and management of government institutions and organizations. They also stated that most of the development agents were corrupt and concentrated on buying vehicles and initiating projects which were not beneficial to the local communities. Another $17.8 \%$ of the respondents stated that they were not consulted when development agents were initiating projects. This means development agents used the top-bottom approach when trying to solve climate variability-related problems which is a wrong approach in project implementation. Twelve per cent of the respondents stated that pastoralists were marginalized and that their views were not taken into consideration. Another $6.8 \%$ of the respondents stated leaders were not from Isiolo County, and so they were not well versed with the local communities' priorities. Finally, $1.3 \%$ of the respondents said that people were not united; hence, they were not in a position to voice their grievances with one voice.

\section{The most suitable organization to initiate adaptive strategies}

Figure 5 shows that the government was ranked highly $(75 \%)$ as the most suitable agent to initiate suitable adaptive strategies against the negative effects of climate variability in the study area. Twenty per cent of the respondents indicated that NGOs were the best suited, while $5 \%$ said that the community was the best suited.

\section{Conclusion and recommendations}

The findings of this study indicated that there are development agents who assist livestock keepers whenever

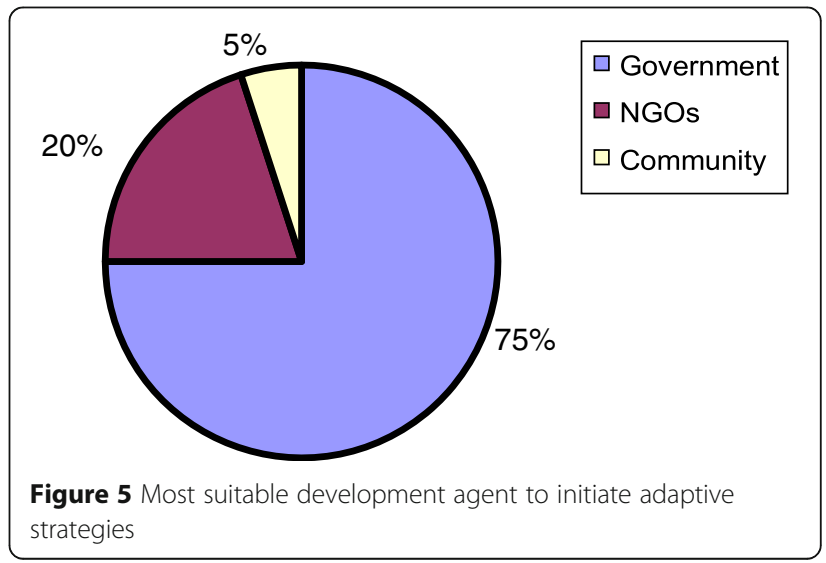


they are faced with climate-related disasters. However, most people felt that they were not getting enough of this assistance since the development agents promote short-term initiatives instead of promoting long-term structural development that would reduce the vulnerability of the local communities. The development agents tend to focus on food relief, and this offers shortterm solutions to crises and also keeps the local community in a chronic state of dependency. The findings also suggest that development agents have not implemented some important adaptive strategies in the study area on a large scale. These strategies include water harvesting technologies, restocking and destocking, irrigation, handling security issues, planting of trees and offering employment. This is attributed to poor leadership, selfishness and marginalization. This means that development agents working in the study area lack coordination and they also emphasize their own views concerning adaptive strategies relating to climate variability. In most cases, inappropriate interventions were put in place such as providing maize to the community when what they really needed was livestock for restocking.

There is need for proper coordination of development agents assisting livestock communities in Isiolo County. There is also need for government departments, NGOs and faith-based organizations to ensure full engagement and effective participation of the local communities in the conception, design and implementation of sustainable solutions to reverse the effects of climate variability.

\section{Acknowledgements \\ Our deepest appreciation and gratitude is extended to the following people for their support in various capacities. I thank the management of KALRO for granting me time to conduct this study. Special thanks go to the enumerators who assisted in data collection while in the field. We are also grateful to the individuals who participated in providing information for this study.}

\section{Authors' contributions}

AWK identified the research site, recruited the enumerators and collected and analysed the data. EGT's contribution included data analysis and compiling and editing the work. JGW's contribution included data analysis and compiling and editing the work. All authors read and approved the final manuscript.

\section{Authors' information}

Dr. Anastasia Wanjiku Kagunyu is a PhD holder from the University of Nairobi. She is a Senior Research Officer at Kenya Agricultural Research Institute, working as a socio-economist. She has coordinated many projects funded by World Bank and European Union in the arid and semi-arid regions of Kenya. An expert in policy-related work and has a rich wealth in research, community development, university lecturing and monitoring and evaluation. Have worked with local and international organizations based in Kenya. Has published 27 academic papers and reports in international journals and conferences.

Mr. Elias Gitonga Thuranira has extensive experience in statistics and biometrics. He holds an MSc in statistics from the University of Nairobi. Mr. Joseph Gatura Wanjohi has extensive experience in statistics and biometrics. He has completed his MSc in statistics from the Catholic University of Eastern Africa. He was a project coordinator of SOS based in Nairobi. He has a wealth of experience in instructing and teaching having been in the profession for over 20 years.

\section{Competing interests}

The authors declare that they have no competing interests.

\section{Publisher's Note}

Springer Nature remains neutral with regard to jurisdictional claims in published maps and institutional affiliations.

\section{Author details}

${ }^{1}$ Kenya Agricultural and Livestock Research Organisation-Sericulture, P.O. Box 7116-01000, Thika, Kenya. ${ }^{2}$ Kenya Agricultural and Livestock Research Organisation-Kabete, P.O. Box 57811-00200, Nairobi, Kenya. ${ }^{3}$ Catholic University of Eastern Africa, P.O. Box 62157-00200, Nairobi, Kenya.

Received: 3 August 2017 Accepted: 3 October 2017

Published online: 21 December 2017

\section{References}

Below, T., A. Artner, R. Siebert, and S. Sieber. (2010). Micro-level practices to adapt to climate change for African small scale farmers: A review of selected literature. The International Food Policy Research Institute (IFPRI) Discussion Paper. Washington: International Food Policy Research Institute. pp. 20006-1002

Connolly-Boutin L. and Barry Smit (2016). Climate change, food security, and livelihoods in sub-Saharan Africa. Regional Environmental Change, 2016, Volume 16, Number 2, Page 385. Available at: http://citations.springer.com/ item?doi=10.1007/s10113-015-0761-x.

G.O.K. 2005. Isiolo District vision and strategy, 2005-2015. Nairobi: Government of Kenya.

G.O.K. 2012. Isiolo District short rains 2011/12 assessment report. Nairobi: Government Printers.

G.O.K. 2013. Isiolo County integrated development plan. 2013-2017. Nairobi: Government Printers.

Huho, (2016). Climate change knowledge gap in education system in Kenya. International Journal of Innovation and Research in Educational Sciences. Volume 2, Issue 3, ISSN (Online): 2349-5219. Available from: https://www. researchgate.net/publication/279179079_Climate_Change_Knowledge_Gap_ in_Education_System_in_Kenya. Reviewed on 4th September 2017.

IPCC, (2014). Climate change (2014) impacts, adaptation, and vulnerability. Part B: Regional aspects. Contribution of Working Group II to the Fifth Assessment Report of the Intergovernmental Panel on Climate Change Cambridge University Press, Cambridge, United Kingdom and New York.

Kanywithia, M. (2010). The Kenya Climate Change Working Group (KCCWG) process, in the farmer's voice. The Bi-Monthly Magazine for National Federation of Agricultural Producers, 2(2): pp 5-6.

Kimani, E., G. Ogendi and P. Makenzi 2015. An evaluation of climate change indigenous coping and adaptation strategies for sustainable agro-pastoral based livelihoods in Baringo County, Kenya. IOSR Journal of Environmental Science, Toxicology and Food Technology. Volume 8, Issue 8 Ver. III (Aug. 2014). PP 38-58.

Nicholson, S.E. 2014. A detailed look at the recent drought situation in the Greater Horn of Africa. Journal of Arid Environments 103 (1): 71-79.

Nkedianye, D., J. de Leeuw, J.O. Ogutu, M.Y. Said, T.L. Saidimu, S.C. Kifugo, D.S. Kaelo, and R.S. Reid. 2011. Mobility and livestock mortality in communally used pastoral areas: The impact of the 2005-2006 droughts on livestock mortality in Maasailand. Pastoralism: Research, Policy and Practice 1 (17): 1-17.

Republic of Kenya, 2012. Sessional Paper No. 8 of 2012 on the National Policy for the Sustainable Development of Northern Kenya and other Arid Lands. Nairobi: Ministry of State for Development of Northern Kenya and other Arid Lands.

Thornton, P. K., and L. Lipper. (2014). How does climate change alter agricultural strategies to support food security? IFPRI Discussion Paper 1340. Washington: International Food Policy Research Institute (IFPRI) and Food and Agriculture Organization (FAO). http://ebrary.ffpri.org/cdm/ref/collection/p15738coll2/id/ 128124.

Yazan, A. M. E., Nyariki, D. M., Wasonga, V. O. and Ekaya, W. N. (2012). Transient poverty among pastoral households in the semi-arid lowland of Baringo District, Kenya, Ozean Journal of Social Sciences 5(1). 